\title{
IAMJ
}

INTERNATIONAL

AYURVEDIC

MEDICAL JOURNAL

\section{AN ANATOMICAL REVIEW OF PRATARA SANDHI W. S. R. TO LUMBAR ANKYLOSING SPONDYLITIS}

\author{
Rikal Kailas $^{1}$, Kavitha Rikal ${ }^{2}$ \\ ${ }^{1}$ Assistant Professor, Dept. of Rasashastra and Bhaishajya Kalpana \\ ${ }^{2}$ Assistant Professor, Dept. of. Rachana Shareera \\ Kala Ashram Ayurveda Medical College and Hospital, Gogunda, Udaipur, Rajasthan, India
}

Email: drrikalkailas@gmail.com

\section{https://doi.org/10.46607/iamj01p4052020}

(Published online: July 2020)

Open Access

(C) International Ayurvedic Medical Journal, India 2020

Article Received: 05/16/2020 - Peer Reviewed: 06/18/2020 - Accepted for Publication: 06/18/2020

Check for updates

\begin{abstract}
Introduction: Ankylosing Spodylitis ${ }^{1}$ is a chronic inflammatory disorder that primarily involves the sacro iliac joint of the lumbar region. It is characterized by musculo skeletal pain, stiffness and immobility of spine and is one of the most common disease of the spine. Meeting place of two bones are known as Sandhi ${ }^{2,3}$. Total eight types of Sandhis ${ }^{4}$ are explained by Acharya Sushruta according to their shape and their movement. KORA, Ulukala, Samudga, Pratara, Tunnasevani, Vayasatunda, Mandala and Sankhavarta. Pratara Sandhi ${ }^{5}$ can be compared to joints of vertebral column and these joints are also considered in the context of Alpachala Sandhi ${ }^{6}$.

Methods: The main objective of this study is aimed at Comprehensive Study and Conceptual Study on Kati Trika Prushtavamsha Sandi Shareera as mentioned in the Classics, Study the Structural Abnormalities of the Anatomy of Vertebral Column in Lumbar Ankylosing Spondylitis and to compare the Normal Radiological Structure of Lumbo Sacral Region with the Confirmed 30 cases of Lumbar Ankylosing Spondylitis.

Results: All the Patients were observed before treatment by Objective and Subjective Criteria.

Conclusion: As per the Study, Lumbar Ankylosing Spondylitis is more prone in young men than young women and lack of Spinal mobility with occupation has major role in this disease.
\end{abstract}


Keywords: Lumbar Ankylosing Spondylitis, Abnormalities of Vertebral Column, Kati Trika Prushtavamsha Sandi Shareera.

\section{INTRODUCTION}

Life is the combination of four factors, namely Shareera, Indriya, Satwa and Athma. Human Anatomy is the science that deals with the study of formation and structure of human body and this Structural Knowledge is foremost aspiration in medical profession. In Ayurveda Samhitha all the Acharya had described the whole body in six to six parts i.e. Shadangha Shareera. Prushtavamsa ${ }^{7}$ or Vertebral Column is at the Prushta Bhaga of the Madhyama Shareera $^{8}$. The Sandis between KASHERUKA Of PRUSHTA VAMSHA are Patara in nature. The reference of Prushta Vamsha and Kasherukas are few in Ayurvedic Samhithas. Acharya Susruta had mentioned it while describing the number of bones, type of joints, Marma Sthana etc. also he mentioned twenty-four Sandi in Prushta Pradeesha, while belongs to Pradhara variety among the eight types of Sandis. The number of Vertebra present in the Prushta Pradeesha is thirty in number by Susrutha, Forty-five by Charaka are classified under VALAYASTHI. Ankylosing Spondylitis is a chronic inflammatory disorder that primarily involves the Sacro iliac joint of the lumbar region. It is characterized by Musculo Skeletal pain, stiffness and immobility of spine. It is the major burden now a days. In this study an attempt has been made to collect all the literature regarding $\mathrm{Kati}^{9} \mathrm{Tika}$ Prushta Vamshagada Sandi Shareera from wide range of classical textbooks and reliable sources. Then compared its normal anatomy with pathological changes in Asti Majjagadavata ${ }^{10}$ (Ankylosing Spondylitis) by using radiological observations of 30 cases.

\section{Aim and Objectives:}

> Comprehensive Study and Conceptual Study on Kati Trika Prushtavamsha Sandi Shareera as mentioned in the Classics.

$>$ To Study the Structural Abnormalities of the Anatomy of Vertebral Column in Lumbar Ankylosing Spondylitis.

$>$ To Compare the Normal Radiological Structure of Lumbar Region with the Confirmed 30cases of Lumbar Ankylosing Spondylitis.

\section{Analysis and Interpretations:}

Present study was conducted among 30 patients ranging from age group of 20 to 50 with both sex, all were suffering from Ankylosing Spondylitis. All patients were observed before treatment by both objective and subjective criteria and following results were incurred based on the observation.

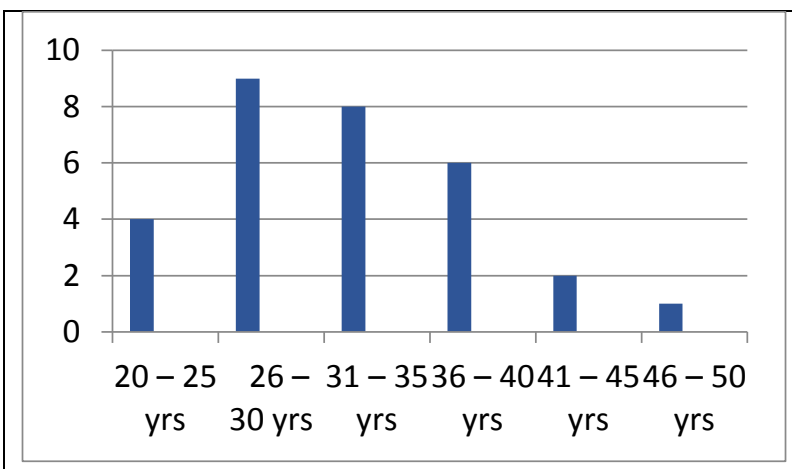

Graph 1: Showing age wise incidence of Ankylosing Spondylitis.

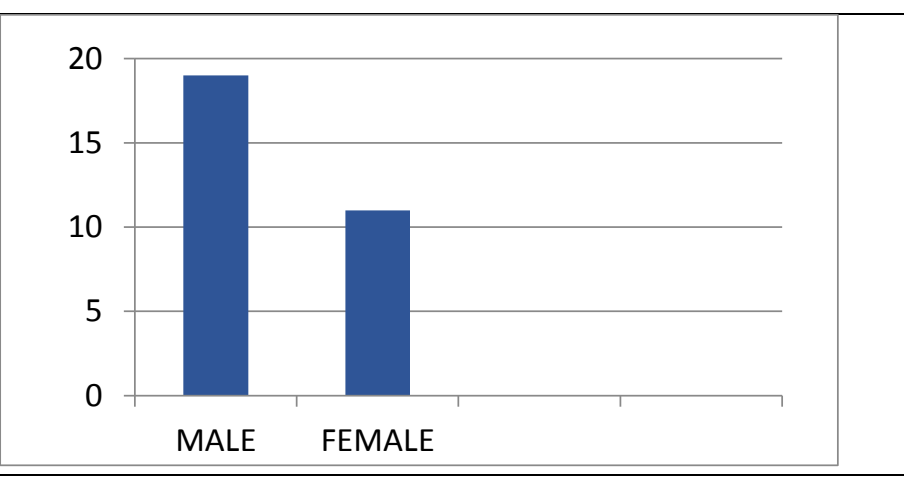

Graph 2: Showing Sex wise incidence of Ankylosing Spondylitis. 


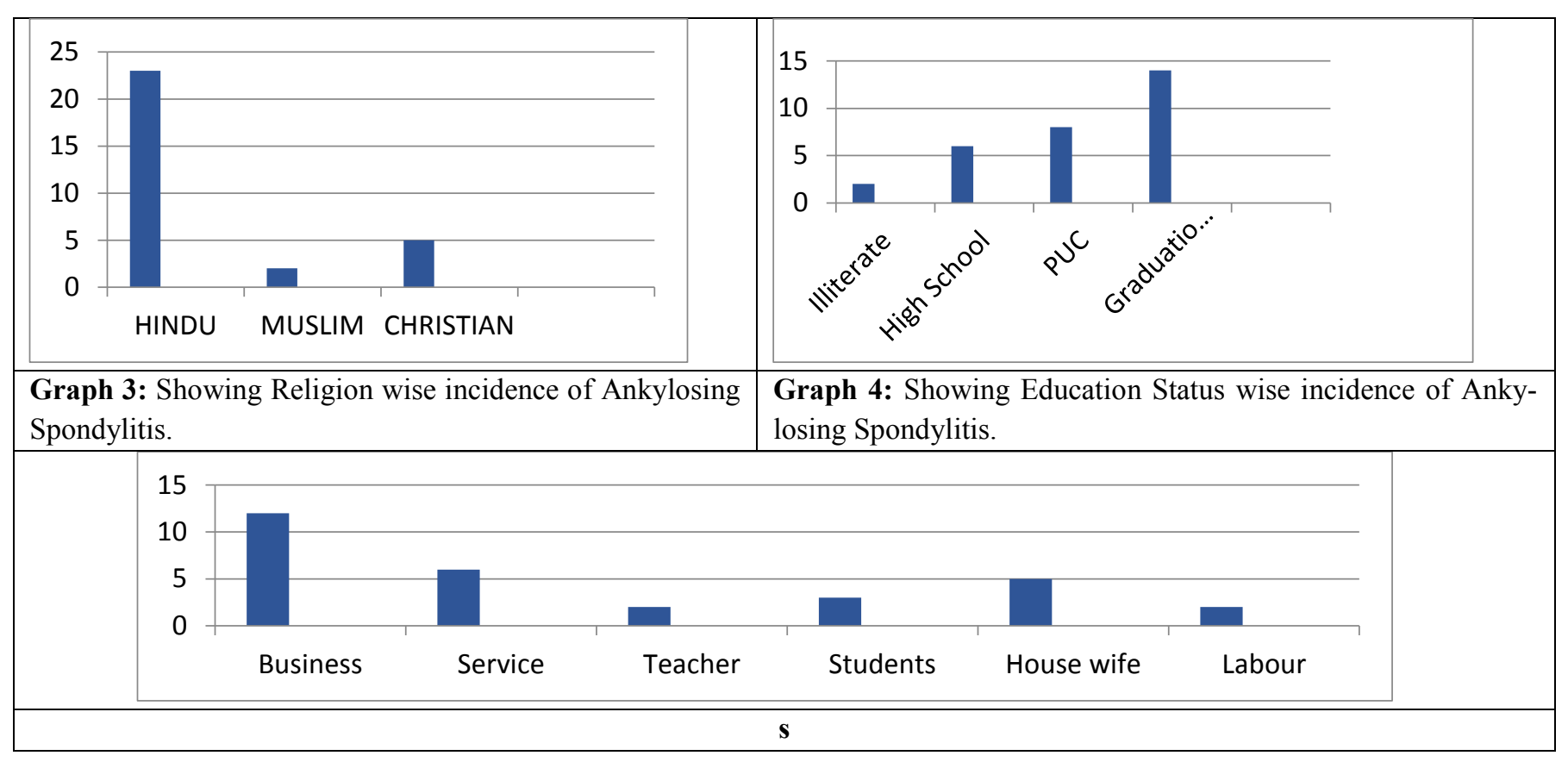

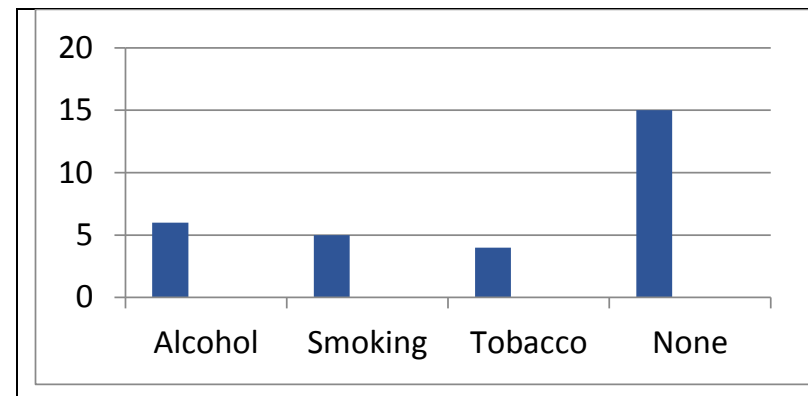

Graph 6: Showing Addiction wise incidence of Ankylosing Spondylitis.

\begin{tabular}{|l|l|l|l|}
\hline S.N & Structural Changes & No. of. Patients & $\%$ \\
\hline 1. & Osteophytes & 30 & 100 \\
\hline 2. & Narrow Joint Space & 30 & 100 \\
\hline 3. & Erosions & 30 & 100 \\
\hline 4. & Soft Tissue Swelling & 30 & 100 \\
\hline
\end{tabular}

Table 1: Showing the bar diagram Structure wise incidence of Ankylosing Spondylitis.

\begin{tabular}{|l|l|l|l|l|l|}
\hline S.N & Ruja & Normal & Mild & Moderate & severe \\
\hline 1. & $\begin{array}{l}\text { Lateral lumbar } \\
\text { flexion }\end{array}$ & Absent & $\begin{array}{l}>10 \\
\mathrm{~cm}\end{array}$ & $5-10 \mathrm{~cm}$ & $<5 \mathrm{~cm}$ \\
\hline 2. & $\begin{array}{l}\text { Forward lum- } \\
\text { bar flexion }\end{array}$ & Absent & $>4 \mathrm{~cm}$ & $2-4 \mathrm{~cm}$ & $<2 \mathrm{~cm}$ \\
\hline 3. & $\begin{array}{l}\text { Maximum } \\
\text { inter-malleolar } \\
\text { distances }\end{array}$ & Absent & $\begin{array}{l}>100 \\
\mathrm{~cm}\end{array}$ & $\begin{array}{l}70-100 \\
\mathrm{~cm}\end{array}$ & $\begin{array}{l}<\mathrm{cm} \\
\mathrm{cm}\end{array}$ \\
\hline
\end{tabular}

Table 3: Showing the bar diagram Ruja Grade wise incidence of Ankylosing Spondylitis.

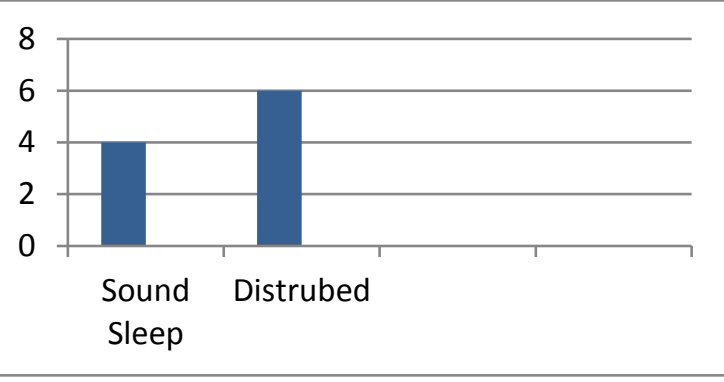

Graph 7: Showing NIDRA wise incidence of Ankylosing Spondylitis.

\begin{tabular}{|l|l|l|l|}
\hline S. N & $\begin{array}{l}\text { Sthambha } \\
\text { (Morning Stiffness) }\end{array}$ & $\begin{array}{l}\text { No. of. } \\
\text { Patients }\end{array}$ & $\%$ \\
\hline 1. & Grade-0 (normal) & 00 & 00 \\
\hline 2. & Grade-1 (<3hrs) & 00 & 00 \\
\hline 3. & Grade-2 $(3 \mathrm{hrs})$ & 03 & 10 \\
\hline 4. & Grade-3 $(3-4 \mathrm{hrs})$ & 12 & 40 \\
\hline 5. & Grade-4 ( > 4hrs $)$ & 15 & 50 \\
\hline
\end{tabular}

Table 2: Showing the bar diagram Sthambha Grade wise incidence of Ankylosing Spondylitis.

\begin{tabular}{|l|l|l|l|}
\hline S.N & $\begin{array}{l}\text { Lateral Lumbar } \\
\text { Flexion }\end{array}$ & $\begin{array}{l}\text { No. of. } \\
\text { Patients }\end{array}$ & $\%$ \\
\hline 1. & Grade-0 & 00 & 00 \\
\hline 2. & Grade-1(mild) & 02 & 07 \\
\hline 3. & Grade2-(Moderate) & 15 & 50 \\
\hline 4. & Grade-3(Severe) & 13 & 43 \\
\hline
\end{tabular}

Table 4: Showing the bar diagram Pain during Lumbar lateral flexion Grade wise incidence of Ankylosing 


\begin{tabular}{|c|c|c|c|c|c|c|c|c|c|c|c|}
\hline & & & & & & \multicolumn{6}{|c|}{ Spondylitis } \\
\hline S.N & \multicolumn{2}{|c|}{ Forward Lumbar Flexion } & \multicolumn{2}{|c|}{ No. of. Patients } & $\%$ & \multirow[t]{2}{*}{ S.N. } & \multirow{2}{*}{$\begin{array}{l}\text { Maximum Inter } \\
\text { Malleolar Distance }\end{array}$} & \multirow{2}{*}{\multicolumn{2}{|c|}{\begin{tabular}{|l|} 
No. of. \\
Patients
\end{tabular}}} & \multirow{2}{*}{\multicolumn{2}{|c|}{$\%$}} \\
\hline 1. & \multicolumn{2}{|l|}{ Grade-0 } & \multicolumn{2}{|l|}{00} & 00 & & & & & & \\
\hline 2. & \multicolumn{2}{|l|}{ Grade-1(mild) } & \multicolumn{2}{|l|}{02} & 07 & 1. & Grade- 0 & \multicolumn{2}{|c|}{00} & \multicolumn{2}{|l|}{00} \\
\hline 3. & \multicolumn{2}{|l|}{ Grade-2(Moderate) } & \multicolumn{2}{|l|}{15} & 50 & 2. & Grade-1(mild) & \multicolumn{2}{|c|}{02} & \multicolumn{2}{|l|}{07} \\
\hline 4. & \multicolumn{2}{|l|}{ Grade-3(Severe) } & \multicolumn{2}{|l|}{13} & 43 & 3. & Grade 2 (Moderate) & \multicolumn{2}{|c|}{15} & \multicolumn{2}{|l|}{50} \\
\hline & & & & & & 4. & Grade-3(Severe) & \multicolumn{2}{|c|}{13} & \multicolumn{2}{|l|}{43} \\
\hline \multicolumn{6}{|c|}{$\begin{array}{l}\text { Table 5: Showing the bar diagram Pain during Forward Lumbar } \\
\text { flexion Grade wise incidence of Ankylosing Spondylitis }\end{array}$} & \multicolumn{6}{|c|}{$\begin{array}{l}\text { Table 6: Showing the bar diagram Pain during Maxi- } \\
\text { mum Inter Malleolar Distance Grade wise incidence of } \\
\text { Ankylosing Spondylitis }\end{array}$} \\
\hline S.N & Grade & \multicolumn{4}{|c|}{ Changes } & S.N & Sacro-illiac & & & $\%$ & \\
\hline 1. & Grade-0(Normal) & None & & & & & Changes & Pat & ients & & \\
\hline 2. & Grade-1(Minimal) & $\begin{array}{l}\text { Suspicic } \\
\text { changes }\end{array}$ & is (Patchy & artic & & 1. & Grade-0 & 00 & & 00 & \\
\hline 3. & Grade-2(Moderate) & Loss of & definition a & he e & & 2. & Grade-1 & 00 & & 00 & \\
\hline & & $\begin{array}{l}\text { of joint } \\
\text { minimal }\end{array}$ & $\begin{array}{l}\text { with some } \\
\text { rosion. }\end{array}$ & clero & & 3. & Grade-2 & 00 & & 00 & \\
\hline 4. & Grade-3(Severe) & Definite & clerosis on & th $\mathrm{s}$ & & 4. & Grade-3 & 13 & & 86 & \\
\hline & & $\begin{array}{l}\text { with } b \\
\text { margins }\end{array}$ & $\begin{array}{l}\text { rring and } \\
\text { loss of joint }\end{array}$ & $\begin{array}{l}\text { adist } \\
\text { ace. }\end{array}$ & & 5. & Grade-4 & 02 & & 14 & \\
\hline 5. & Grade 4 (Ankylosis) & Comple & fusion of $\mathrm{j}$ & & & & & & & & \\
\hline $\begin{array}{l}\text { Table } \\
\text { Grade i }\end{array}$ & $\begin{array}{l}\text { 7: Showing the bar } \\
\text { incidences of Ankylos }\end{array}$ & $\begin{array}{l}\text { diagram } \\
\text { ng Spond }\end{array}$ & $\begin{array}{l}\text { acro-illiac } \\
\text { itis. }\end{array}$ & ange & ise & $\begin{array}{l}\text { Table } \\
\text { Grade i }\end{array}$ & $\begin{array}{l}\text { 8: Showing the bar diag } \\
\text { ncidences of Ankylosing }\end{array}$ & por & $\begin{array}{l}\text { Sacro-illi; } \\
\text { dylitis Pa }\end{array}$ & $\begin{array}{l}\text { Change } \\
\text { ients. }\end{array}$ & wise \\
\hline S.N & Family History & No. 0 & Patients & $\%$ & & S.N & Effected Area & & $\begin{array}{l}\text { No. } \\
\text { tients }\end{array}$ & f. Pa- & \\
\hline 1. & Present & 24 & & 80 & & 1. & Sacro-illiac Joint & & 15 & & 50 \\
\hline 2. & Absent & 06 & & 20 & & 2. & Lumbo-Sacral Juncti & & 05 & & 17 \\
\hline & & & & & & 3. & Lumbar Vertebral Joi & & 10 & & 33 \\
\hline $\begin{array}{l}\text { Table } \\
\text { dence o }\end{array}$ & $\begin{array}{l}\text { 9: Showing the bar } \\
\text { f Ankylosing Spondy }\end{array}$ & $\begin{array}{l}\text { iagram } \\
\text { is. }\end{array}$ & nily Hist & & & $\begin{array}{l}\text { Table } \\
\text { incider }\end{array}$ & $\begin{array}{l}\text { 10: Showing the bar } \\
\text { ce of Ankylosing Spo }\end{array}$ & & $\begin{array}{l}\text { am Eff } \\
\text { tis. }\end{array}$ & ted $\operatorname{Ar}$ & vise \\
\hline
\end{tabular}

\section{Radiological Findings:}

\begin{tabular}{|l|l|l|}
\hline & $\begin{array}{l}\text { Normal Sacro-illiac Joint } \\
\text { Grade-3 Sacro-illiitis } \\
\text { with Sclerosis. } \\
\text { Decreasedjoint Space. } \\
\text { PartialAnkylosing } \\
\text { Spondylitis. }\end{array}$ \\
\hline $\begin{array}{l}\text { Normal Sacro-illiac X-ray no.1 } \\
\text { A.P.View }\end{array}$ & $\begin{array}{l}\text { Sacro-illiac X-ray no.2 } \\
\text { A.P. View with Partial Ankylosing } \\
\text { Spondylitis }\end{array}$ \\
\hline
\end{tabular}




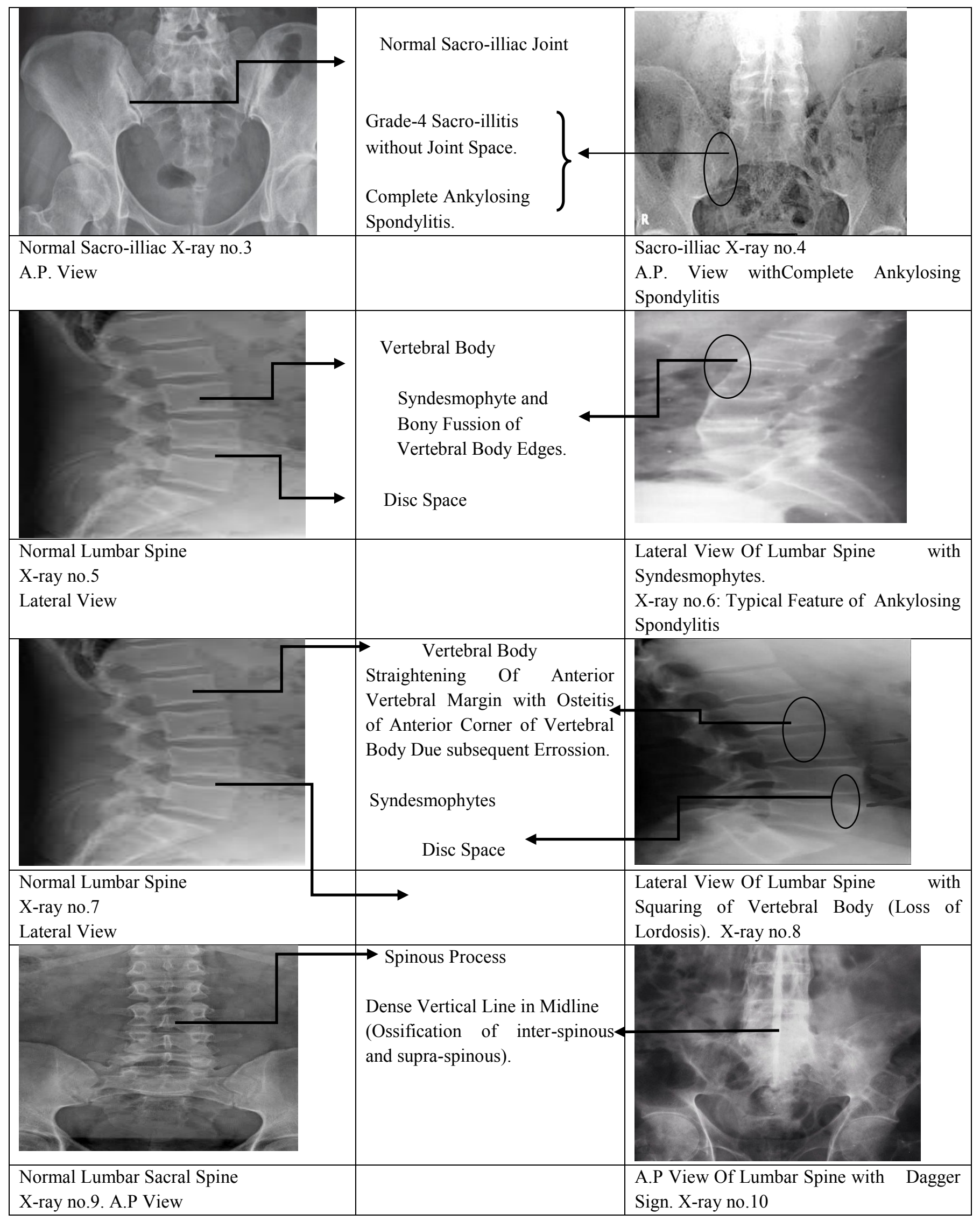




\begin{tabular}{|c|c|c|}
\hline$\frac{2}{2} \frac{5}{2}=\frac{5}{9}$ & $\begin{array}{l}\text { Spinous Process } \\
\text { Superior End Plate } \\
\text { Slerosis, Shiny Corner. } \\
\text { Sydesmophytes } \\
\text { (Ossification of Annulus } \\
\text { Fibrosis) }\end{array}$ & $x_{x \rightarrow 3}$ \\
\hline $\begin{array}{l}\text { Normal Lumbar Sacral Spine } \\
\text { X-ray no.11 A.P View }\end{array}$ & 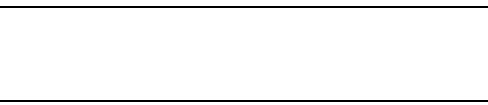 & $\begin{array}{l}\text { Lateral View Of Lumbar Spine with } \\
\text { Bamboo Spine. X-ray no.12 }\end{array}$ \\
\hline & $\begin{array}{l}\text { Syndesmophytes } \\
\text { Inflamed Bone Marrow } \\
\text { (Degeneration of Anterior } \\
\text { Vertebral Edge of L-5 } \\
\text { Vertebrae) }\end{array}$ & \\
\hline $\begin{array}{l}\text { Normal Lumbar Spine } \\
\text { X-ray no.13 Lateral View }\end{array}$ & & $\begin{array}{l}\text { Lateral View Of Lumbar Spine with } \\
\text { Romanus Lesion. X-ray no.14 }\end{array}$ \\
\hline & $\begin{array}{l}\text { Superior End Plate } \\
\text { Syndesmophytes at L-4 } \\
\text { Intervertebral Disc Space } \\
\text { Height Reduction of Interverte- } \\
\text { bral Disc Space and Sclerosis of } \\
\text { End Plate of L-4 and L-5. } \\
\text { Erosive Defect of Superior end } \\
\text { Plate of L-5 with Signal loss of } \\
\text { Surrounding Bone Marrow }\end{array}$ & \\
\hline $\begin{array}{l}\text { Normal Lumbar Spine } \\
\text { X-ray no.15 Lateral View }\end{array}$ & & $\begin{array}{l}\text { Lateral View Of Lumbar Spine r with } \\
\text { Squaring of Vertebral Body (Loss of } \\
\text { Lordosis). X-ray no.16 }\end{array}$ \\
\hline
\end{tabular}

\section{DISCUSSION}

Kati is considered as the waist region were dress is worn and is cylindrical region of Madhya Shareera among the Shadanga Of Shareera, Shroniphalaka themselves are called as Kati. The limitations of this region are already given by classical texts. Above is limited by Nabhi, below by Medra and Muskha. According to the modern science, umbilicus belongs be- tween L-3 and L-4 region. Discussion on DiseaseOsteophytes: Vata Dosha as Asraya and Asrayi Bhava Sambhanda with Asthi. Vata Vriddi Leads to Asthi Kshaya or Asthi Vriddi. This Asthi Vriddi may be corelated with osteophytes. Asthi Vriddi or Adi Asthi is the pathological signs of Asti Majjagata Dathu Vaada and this may lead to the fusion of vertebrae. Dehydration of Synovial membrane and inter vertebral disc, 
Vitiated Vata Dosha gives Ruksha and Khara Guna on the Kati Trika Prushtavamsha, due to this Sleshaka Kapha with in the joints (Jaleeya Guna gets loss) due to this dehydration, movement within the joints get impaired. Due to this Ruksha Guna of Vata friction between the vertebrae are occurs and may close to each other (fusion). The main function of Snayu is Sandhi Bandhana. When aggravated Vata lodges in the Snayus of Kati Trika Prushtavamsha leads to Sna$y u$ Vikriti resulting in rigidness due to its Ruksha Guna and it may affect the surrounding structures like nerve root compression on Kati Trika Pradesha. When Vata Dosha affect the Asthi and Majja Dhatu leads to Asthi Majja Dhatu Kshaya, due to its Ruksha Guna. Narrowing of joint space is due to Shotha in Sandhi, erosion is due to Asthi Majja Kshaya. When aggravated Vata affecting the Sleshmadara Kala resulting thickening and gives inflammatory symptoms with pain on inter vertebral joints. Aggravated Vata when effects on Mamsa Snayu and Kantara undergoes Shoshana due to the Ruksha Guna of Vata leads to wasting and stiffness on it. Asti Majjagata Dhatu vata maybe correlated with Ankylosing spondylitis since its symptoms are also observed here, its pathology leads to functional and structural abnormality in Kati Trika Prushtavamsha. Discussion on Clinical StudyData observed from study of thirty patients are being discussed below, Age: As per the study incidence was highest in the age of 20-25 years contributing 13 percentage, 30 patients in the age group of 26-30 years, 27 percentage in $31-35,20$ percentage in $36-40$ years of age, 07 percentage in 41-45 years of age, 03 percentage in $46-50$ years of age. It is most common (30 percentage) in the age between 26-30 years of age. Here present data signifies age factor must have influence over it due to the sedentary habits or life style, Sex:63 percentage of patients were male and 37 percentage of patients were female, here study says that male sex is more susceptible for the disease may be due to, there was a tendency for male to have more Severe arthritic change. Male more often had radiological involvement of lumbar spine more restricted lumbar mobility and total spinal flexion. These finding may indicate less severe in female than male.

\section{CONCLUSION}

Present study proves that sacro iliac joint is primarily affected among the three joints that are taken for the study. Morning stiffness and nocturnal back pain were hallmark with different grade. Asti Majjagata Vata may be correlated with Lumbar Ankylosing Spondylitis in modern, because all most all symptoms of Asti Majjaa Gata Vada is similar with this, like $A S$ THIBEDA (stabbing pain on bones), Parvabeda (pain in small joints), Asti Soola (pain in joints), Mamsa Kshaya (depletion of muscle tissue), Bala Kshaya (decreased vitality and strength), Adyasthi (osteophytes), these are the complaints which comes under Asti Padoshaja Vikara, Vinamada is one of the symptoms of Asti Majjagata Datu Vata (bending of body as kyphosis) is the manifestation of Majjavrita Vata. All the patients of the study got relief by doing exercise, movements. As per the study we conclude that lack of spinal mobility with occupation (businesspeople who are sedentary) has major role in lumbar Lumbar Ankylosing Spondylitis through their history taking. Pathologies considered for the differential diagnosis within the Ayurvedic pattern includes Grudrasi, Amavata. Grudrasi was excluded by the patient having other dissimilar features like radiating pain from lumbar area to the lateral sides of leg up to Gulpha Sandhi, Amavata also excluded here due to Constitutional features like fever, anorexeia, vomiting, are uncommon at onset. None of the patients having involvement of inter lumbar joints and lumbo sacral joints without involvement of sacro iliac joint in Lumbar Ankylosing Spondylitis, here it shows that Sacro iliac joint is primarily affected compared with other joints that are mentioned above.

\section{ACKNOWLEDGEMENT:}

We are Thankful to the Management of Kala Ashram Ayurveda Medical College \& Hospital Udaipur Rajasthan, for their kind support during the entire work. 


\section{REFERENCES}

1. Vander Heijde D, Baraf HS, Ramos-Remus C, et al. Evaluation of the efficacy of etoricoxib in Lumbar Ankylosing Spondylitis: results of a fifty-two-week, randomized, controlled study. Arthritis Rheum 2005; Pp: 1205, Page No:15.

2. Amaramishra, Amarakosha with Ramashrami commentary of Bhanuji Dikshitha; Edited by Pandit Haragovinda Shastri; Chaukambha Sanskrit Sansthana; Varanasi; Reprint 2006; Pp: 664; Page No.: 529.

3. Vaidyaka Shabda Sindhu compiled by Kaviraja Umeshchandra Gupta; Revised and enlarged second edition by Kaviraj Nagendranath, Choukamba Orientalia; print 1999; Pp:1999; Page No:1077.

4. Sushruta. Yadavji Trikamji Accharya, editor. Sushrutha Samhitha with Nibandha Sangraha of Dalhanacharya. $8^{\text {th }}$ ed. Varanasi: Choukambha Orientalia; 2008. Pp- 824, Page No. 367

5. Sushruta. Yadavji Trikamji Accharya, editor. Sushrutha Samhitha with Nibandha Sangraha of Dalhanacharya. 8thed. Varanasi: Choukambha Orientalia; 2008. Pp- 824, Page No- 367.

6. Sushruta. Yadavji Trikamji Accharya, editor. Sushrutha Samhitha with Nibandha Sangraha of Dalhanacharya. 8thed. Varanasi: Choukambha Orientalia; 2008. Pp- 824, Page No. 366.

7. Sushrutha, Sushrutha Samhitha with Nibandha Sangraha commentary of Dalhanacharya and Nyaya Chandrika Panjika commentary of Gayadasacharya; Edited by Vaidya Jadavji Trikamji Acharya and Narayana Ram Acharya; 8th edition; Chaukambha Orientalia; Varanasi; 2005; Pp: 824; Page No.: 365

8. Agnivesha, Charaka Samhitha with Ayurveda Dipika commentary of Chakrapanidatta; Edited by Vaidya Jadavji Trikamji Acharya; Chaukambha Orientalia; Varanasi; Reprint 2007; Pp: 738; Page No.: 337

9. Sushruta. Yadavji Trikamji Accharya, editor. Sushrutha Samhitha with Nibandha Sangraha of Dalhanacharya. 8thed. Varanasi: Choukambha Orientalia; 2008. Pp- 824, Page No- 45

10. Yograthnakara, By Dr. Indradeva Thripati and Dr. Dayashankar Thripati, Edited Yogaratnakara with Vaidyaparabha, Hindi commentary 1st edition 1998, Krishnadas Academy Oriental; Varanasi Pp:401, Page No-481.

\section{Source of Support: Nil}

\section{Conflict of Interest: None Declared}

How to cite this URL: Rikal Kailas \&Kavitha Rikal: An Anatomcal Review Of Pratara Sandhi W. S. R. To Lumbar Anky-Losing Spondylitis. International Ayurvedic Medical Journal \{online\} 2020 \{cited July, 2020\} Available from: http://www.iamj.in/posts/images/upload/2367_2374.pdf 